

\title{
Leptospiral antibodies in wild boars (Sus scrofa) bred in Brazil
}

Fornazari F (1), Camossi LG (1), Silva RC (1), Guazzelli A (1), Ribeiro MG (1), Chiacchio SB (2), Langoni $\mathrm{H}(1)$

(1) Department of Veterinary Hygiene and Public Health, School of Veterinary Medicine and Animal Husbandry, São Paulo State University (UNESP - Univ Estadual Paulista), Botucatu, São Paulo State, Brazil; (2) Department of Veterinary Clinical Sciences, School of Veterinary Medicine and Animal Husbandry, São Paulo State University (UNESP - Univ Estadual Paulista), Botucatu, São Paulo State, Brazil.

\begin{abstract}
In the recent years, the wild boar (Sus scrofa) trade has increased in Brazil. The present study aimed to detect Leptospira spp. infection in 308 blood samples from wild boars bred in São Paulo state, Brazil. The microscopic agglutination test (MAT) was performed using 29 serovars. Sixty three $(63 ; 20.45 \%)$ animals tested positive against the serovars Hardjo (29/63; 46.0\%), Copenhageni $(11 / 63 ; 17.4 \%)$, Pomona (8/63; 12.7\%), Pyrogenes (4/63; 6.3\%), Wolfii (4/63; 6.3\%), Autumnalis (3/63; 4.7\%), Icterohaemorraghiae $(2 / 63 ; 3.1 \%)$, and Hardjo-miniswajezak $(1 / 63 ; 15.8 \%)$. These results indicate that captive wild boars were infected with Leptospira spp. and may represent a source of infection to humans and other animals.
\end{abstract}

Key words: wild boar, Sus scrofa, Leptospira spp., MAT, zoonosis.

Wild boar (Sus scrofa) is a European species brought into South America to be used in hunting games (1). The first commercial breeding facilities in Brazil were established in the state of Rio Grande do Sul in the 1980s due to the increasing interest in this type of meat (2). Leptospirosis - a worldwide infectious disease that affects humans, domestic and wild animals - is caused by Leptospira bacteria and may lead to severe clinical signs, such as reproductive disorders in cattle and swine, besides hemorrhage and renal failure in humans $(3,4)$. Animals infected with leptospirosis can eliminate the pathogen into the environment, acting as a source of infection (5). Due to the increasing trade of wild boar meat in Brazil, the aim of the present study was to detect Leptospira spp. infection in this species (6).

Blood samples were collected from 308 wild boars, 198 (96 females and 102 males) of which were obtained from a slaughterhouse, and 110 (57 females and 53 males) from a farm, both located in São Paulo state, Brazil. Most animals were aged between 6 and 8 months. Although it was not possible to investigate the origin of the slaughterhouse animals, it is known that they were from farms located in São Paulo state. The animals from the farm were bred in an intensive system and received corn and vegetable-based feed.

Samples were sent to the laboratory of the Zoonosis Research Center (NUPEZO) of the São Paulo State University (UNESP), Botucatu, São Paulo state, Brazil. They were analyzed by microscopic agglutination test (MAT), and screened for 29 serovars: Australis, Butembo, Canicola, Djasiman, Hebdomadis, Javanica, Pyrogenes, Shermani, Bratislava, Castellonis, Whitcombi, Sentot, Copenhageni, Panama, Tarassovi, Autumnalis, Bataviae, Cynopteri, Grippotyphosa, Icterohaemorrhagiae, Pomona, Wolffi, Andamana, Patoc, Hardjo, Hardjo-C.T.G., Hardjo-prajitno, Hardjo-bovis, and Hardjominiswajezak. Sera were initially tested at 1:100 dilution, and than those samples presenting positive agglutination were two-fold diluted until 
their final titer. Animals showing titers equal to or higher than 100 were considered positive. If an animal was positive to more than one serovar, the higher was considered.

Results regarding the serological test for leptospirosis were evaluated through chi-square or Fisher's exact test by using the software Epi Info 3.5.1 (Center for Disease Control and Prevention, USA), adopting $\alpha=0.05$.

Sixty-three animals were positive (63/308; $20.4 \%$, CI95\% 16.33-25.32\%), 45 from the slaughterhouse and 18 from the farm. Titers ranged from 100 to 400. Antibodies were detected to the following serovars: Hardjo $(29 / 63 ; 46.0 \%)$, Copenhageni $(11 / 63 ; 17.4 \%)$, Pomona $(8 / 63 ; 12.7 \%)$, Pyrogenes $(4 / 63 ; 6.3 \%)$, Wolfii $(4 / 63 ; 6.3 \%)$, Autumnalis $(3 / 63 ; 4.7 \%)$, Icterohaemorraghiae $(2 / 63 ; 3.1 \%)$, and Hardjominiswajezak $(1 / 63 ; 1.5 \%)$, as shown in Table 1. The most prevalent serovars were Pomona in animal samples from the farm, and Hardjo in those from the slaughterhouse. One animal (female) from the farm presented the same titer (100) to serovars Pyrogenes and Hardjo-miniswajezak, thus it was excluded from the statistical analysis. Females showed a higher risk of infection $(P \leq$ 0.05 ), as shown in Table 2.

Previous studies have reported infection by Leptospira spp. in wild boars in other countries, especially in Europe where this is a native species (7-11). Such studies were performed in freeranging animals, and showed different prevalence due to the diverse conditions of each survey. Comparison with our data is not convenient; however, these studies revealed that wild boars can be infected by Leptospira spp. in various conditions. No studies involving captive wild boars were found in the analyzed literature. To our knowledge, this is the first serologic survey for leptospirosis in wild boars bred for human consumption.

In Brazil, free-ranging wild boars also occur in nature, and are considered a problematic exotic species that affect the environment, native species populations and crop production. In the country, research on leptospirosis and wild boars is extremely scarce. Girio et al. (12) detected $17.9 \%$ (7/39) feral pigs (Sus scrofa) infected by Leptospira

Table 1. Distribution of Leptospira spp. antibodies in wild boars (Sus scrofa) bred in Brazil

\begin{tabular}{|c|c|c|c|c|c|c|c|c|c|}
\hline \multirow[b]{2}{*}{$\begin{array}{l}\text { Place and } \\
\text { gender }\end{array}$} & \multirow[b]{2}{*}{$\begin{array}{l}\text { Positive/n. } \\
\text { (\%) }\end{array}$} & \multicolumn{8}{|c|}{ Positive serovars ${ }^{b}$} \\
\hline & & $\begin{array}{l}\frac{T}{9} \\
\frac{0}{0}\end{array}$ & $\begin{array}{l}\text { O } \\
\frac{0}{0} \\
\frac{D}{D} \\
\frac{2}{2} \\
0 \\
\text { D. } \\
\text { D. }\end{array}$ & $\begin{array}{l}\frac{0}{3} \\
\frac{0}{3} \\
\frac{0}{2} \\
\text { d. }\end{array}$ & 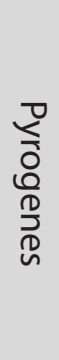 & $\frac{\sum_{\Xi}}{\equiv}$ & 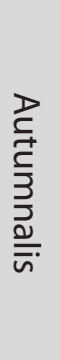 & 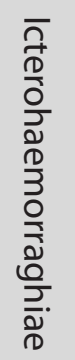 & $\begin{array}{l}\frac{1}{2} \\
\frac{0}{2} \\
\text { 응 } \\
3 \\
\vdots\end{array}$ \\
\hline \multicolumn{10}{|c|}{ Slaughterhouse } \\
\hline Male & $\begin{array}{c}14 / 102 \\
(13.7)\end{array}$ & 8 & 5 & 0 & 0 & 0 & 0 & 1 & 0 \\
\hline Female & $\begin{array}{l}31 / 96 \\
(32.2)\end{array}$ & 21 & 6 & 0 & 0 & 4 & 0 & 0 & 0 \\
\hline \multicolumn{10}{|l|}{ Farm } \\
\hline Male & 9/53 (16.9) & 0 & 0 & 7 & 1 & 0 & 3 & 1 & 0 \\
\hline Female & 9/57 (15.7) & 0 & 0 & 1 & 3 & 0 & 0 & 0 & 1 \\
\hline Total & $\begin{array}{l}63 / 308 \\
(20.45)\end{array}$ & 29 & 11 & 8 & 4 & 4 & 3 & 2 & 1 \\
\hline
\end{tabular}

${ }^{a} n .:$ number of tested animals; ${ }^{b}$ one animal was excluded $(n=62) ;{ }^{c}$ Hardjo M: Hardjo miniswajezak. 
Table 2. Statistical results for the studied places concerning the sex of the animals

\begin{tabular}{|c|c|c|c|c|c|c|}
\hline Variable & Sex & $\mathrm{n}^{\mathrm{a}}$ & $\mathrm{MAT}^{\mathrm{b}}$ & $\begin{array}{l}\text { Percentage; } \\
\text { Cl95 }\end{array}$ & OR $(\mathrm{Cl} 95)^{d}$ & $p^{\mathrm{e}}$ \\
\hline \multirow{2}{*}{$\begin{array}{c}\text { Sex } \\
\text { (slaughterhouse }+ \text { farm) }\end{array}$} & Male & 155 & 23 & $14.8 ; 10.1-21.3$ & \multirow{2}{*}{$2.0(1.1-3.5)$} & \multirow{2}{*}{0.01} \\
\hline & Female & 153 & 40 & $26.1 ; 19.8-33.6$ & & \\
\hline \multirow{2}{*}{ Sex (slaughterhouse) } & Male & 102 & 14 & $13.7 ; 8.4-21.8$ & \multirow{2}{*}{$2.8(1.4-5.8)$} & \multirow{2}{*}{0.00} \\
\hline & Female & 96 & 31 & $31.3 ; 22.8-41.1$ & & \\
\hline \multirow{2}{*}{ Sex (farm) } & Male & 53 & 9 & $17.0 ; 9.2-29.3$ & \multirow{2}{*}{$0.9(0.3-2.5)$} & \multirow{2}{*}{0.53} \\
\hline & Female & 57 & 9 & $15.8 ; 8.6-27.4$ & & \\
\hline
\end{tabular}

${ }^{a}$ n.: number of tested animals; ${ }^{b}$ MAT: microscopic agglutination test (titer $\geq 100$ ); ${ }^{\text {c }}$ frequency of positive animals based on the studied variable (confidence interval $=95 \%$ ); ${ }^{\mathrm{d}}$ OR: odds ratio; ${ }^{\mathrm{e}} p$ : value of $p$ for $a=0.05$.

spp. in Mato Grosso do Sul state, in which the serovars Icterohaemorrhagiae and Copenhageni were the most common.

In the current study, the serovar Hardjo, especially common in cattle, presented high prevalence among animals from the slaughterhouse, which may suggests its participation in the epidemiological cycle of leptospirosis in cattle (5). Wild boars are possibly infected by leptospires eliminated by cattle. Because it was not possible to trace back the origin of these animals, and investigate their sites of origin, we could confirm this hypothesis.

Domestic pigs are frequently infected by the serovars Copenhageni or Pomona (13). Their phylogenetic similarity with wild boars may justify the high number of animals infected by these serovars in the present study. Thus, the wild boar can also be a primary host of several serovars and more studies are required to corroborate this hypothesis.

The serovars Pomona, Pyrogenes, Hardjo, Copenhageni, Icterohaemorraghiae and Autumnalis have already been reported in wild boars (7-12). However, this is the first study describing an infection caused by the serovars Wolfii and Hardjo-miniswajezak.

In conclusion, wild boars bred in Brazil infected by Leptospira spp. may represent a source of infection to humans and other animals. Females appear to have a higher risk of infection. However, the true risk of human infection and the impact of leptospirosis on wild boar trade are unknown. Thus, further studies are required.

\section{COPYRIGHT}

(C) CEVAP 2011

\section{SUBMISSION STATUS}

Received: June 24, 2010.

Accepted: August 8, 2010.

Abstract published online: September 13, 2010.

Full paper published online: February 28, 2011.

\section{CONFLICTS OF INTEREST}

There is no conflict.

\section{ETHICS COMMITTEE APPROVAL}

The present study was approved by the Ethics Committee of the School of Veterinary Medicine and Animal Husbandry, São Paulo State University (UNESP - Univ Estadual Paulista), protocol number 148/2007.

\section{CORRESPONDENCE TO}

HELIO LANGONI, Departamento de Higiene Veterinária e Saúde Pública, Faculdade de Medicina Veterinária e Zootecnia, UNESP, Distrito de Rubião Jr, s/n, Botucatu, SP, 18618000, Brasil. Phone: +55143811 6270. Fax: + 55 143811 6075. Email: hlangoni@fmvz.unesp.br.

\section{REFERENCES}

1. Furtado MM, Kashivakura CK. Artiodactyla Tayassuidae e Suidae (cateto, queixada, javali). In: Cubas ZS, Silva JCR, Catão-Dias JL, editor. Tratado de animais selvagens. São Paulo: Roca; 2006. p. 615-29.

2. Gimenez DL, Mota LSLS, Curi RA, Rosa GJM, Gimenez MA, Lopes CR, et al. Cytogenetic 
and molecular analysis of a European wild boar Sus scrofa scrofa and domestic swine Sus scrofa domesticus. Braz J Vet Res Anim Sci. 2003;40(2):146-54.

3. Langoni H, Da Silva AV, Pezerico SB, De Lima VY. Anti-leptospirose agglutinins in equine sera, from São Paulo, Goiás, and Mato Grosso do Sul, Brazil, 1996-2001. J Venom Anim Toxins incl Trop Dis. 2004;10(3):207-18.

4. Langoni H, Kawaguchi MF, Oshika JC, Teixeira CR. Leptospira spp. antibodies in captive coatis (Nasua nasua Storr, 1780) (Carnivora: Procyonidae). J Venom Anim Toxins incl Trop Dis. 2009;15(4):762-7.

5. Levett PN. Leptospirosis. Clin Microbiol Rev. 2001;14(2):296-326.

6. Marchiori AF, Felício PE. Quality of wild boar meat and commercial pork. Sci Agric. 2003;60(1):1-5.

7. New JC, Delozier K, Barton CE, Morris PJ, Potgieter LN. A serologic survey of selected viral and bacterial diseases of European wild hogs, Great Smoky Mountains National Park, USA. J Wildl Dis. 1994;30(1):103-6.

8. Ebani VV, Cerri D, Poli A, Andreani E. Prevalence of Leptospira and Brucella antibodies in wild boars (Sus scrofa) in Tuscany, Italy. J Wildl Dis. 2003;39(3):718-22.
9. Jansen A, Nöckler K, Schönberg A, Luge E, Ehlert $\mathrm{D}$, Schneider T. Wild boar as possible source of hemorrhagic leptospirosis in Berlin, Germany. Eur J Clin Microbiol Infect Dis. 2006;25(8):5446.

10. Slavica A, Cvetnić Ž, Milas Z, Janicki Z, Turk $\mathrm{N}$, Konjević $\mathrm{D}$, et al. Incidence of leptospiral antibodies in different game species over a 10year period (1996-2005) in Croatia. Eur J Wildl Res. 2008; 54(2):305-11.

11. Espí A, Prieto JM, Alzaga V.Leptospiral antibodies in Iberian red deer (Cervus elaphus hispanicus), fallow deer (Dama dama) and European wild boar (Sus scrofa) in Austrias, Northern Spain. Vet J. 2010;183(2):226-7.

12. Girio RJS, Pereira FLG, Filho MM, Mathias LA, Herreira RCP, Alessi AC, et al. Pesquisa de anticorpos contra Leptospira spp. em animais silvestres e em estado feral da região de Nhecolândia, Mato Grosso do Sul, Brasil. Utilização da técnica de imuno-histoquímica para detecção do agente. Cienc Rural. 2004;34(1):1659.

13. Ramos AC, Souza GN, Lilenbaum W. Influence of leptospirosis on reproductive performance of sows in Brazil. Theriogenology. 2006;66(4):10215. 